\title{
The impact of equity in FDI firms on accountants' loyalty: Application of equity theory and creative application in economics sociological knowledge
}

\author{
Dang Huy Nguyen ${ }^{a}$ and Duc Tai Do ${ }^{b^{*}}$
}

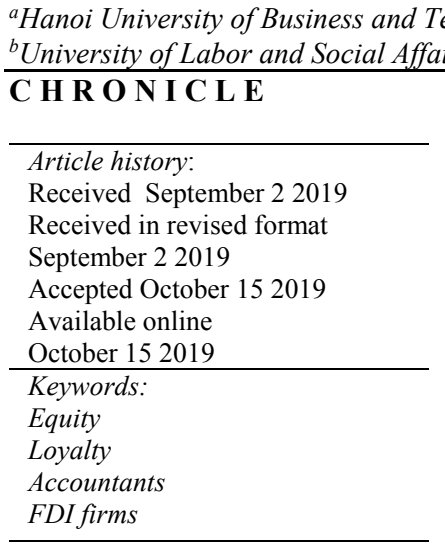

\section{Introduction}

Equity theory is of great importance to employees and organizations. For an individual, equality satisfies an individual's need for control, confidence, a sense of happiness and ethical obligations and for an organizational, equality creates a legal framework for managing and controlling. When the organization shows justice in tackling issues, it can restrict the risk of fraud, enhance trust in management, reduce the fear of being abused and encourage cooperation (Colquitt et al., 2005). Equality in the organization is related to employees' physical and mental health. Inequity in the organization creates stress or pressure at work (Judge \& Colquitt, 2004). When employees have the feeling of comfort at work, they feel attached to the company and devote their best to the work, improve work efficiency thereby contributing to the growth of the organization. Not to mention, companies themselves also save time, minimize the turnover rate and reduce costs (Ngo et al., 2017). Thang Long Industrial Park, Dong Anh District which was established and licensed in 1997, is one of the largest industrial parks in Hanoi. This is a joint venture between Japan and Vietnam, and up to early 2018, Thang Long Industrial Park attracted about 31 foreign investors from Japan, Malaysia, and Singapore. In the global integration era, the race of attracting high-quality human resources, especially in accounting, is one of the hotly debated issues in companies as well as FDI firms in particular. A large portion of the accountants in FDI firms have graduated from university and had the ability to use English or other foreign languages. They are an intellectual team in society with high sensitivity and high demand for equality at work. They are also a class of people with a wide knowledge base and a high need for process control. Hence, it can be said that accountants in FDI firms have greater

* Corresponding author. Tel.: +84904509101

E-mail address: taiketoanquocte@gmail.com (D.T. DO) 
sensitivity to equality than others from sectors of the enterprise. The question is, how equality in an organization affects their loyalty and concretes expression of their attitude and behavior. Therefore, the study of the effects of equality on the loyalty of accountants is necessary.

\section{Equity theory}

One of the first studies on organizational equity belongs to Adams $(1963,1965)$. Nowadays, the theory of equity has been researched and developed by many different authors, including Greenberg (1990) and Lind and Tyler (1988). Equity theory was explained by Adams (1965) through the comparison with what is relevant to others, groups of people, other organizations, etc. and fairness is a factor that builds up the satisfaction of the participants in that relationship. The concept of organizational equity refers to employees' perceptions of the degree to which they are treated equally within the organization and how these perceptions affect the organization's performance as a commitment and satisfaction (Greenberg, 1990). According to Coetzee (2004), descriptions and explanations of equality in the workplace are called organizational equity, which shows the fair and respectful treatment of the managers towards employees. The organizational equity is also understood that everything in the workplace is expressed through the management decisions, which leads to the employees' feeling of reasonableness, equality, clearance and unbiased (Greenberg, 2005; Lee (2007). There are many aspects of the equity theory related to the organization's main outcomes such as employee behavior in the organization (Moorman, 1991), commitment, job satisfaction and trust in management (Alexander \& Ruderman, 1987), work style, management style and managerial judgment (Colquitt, 2001). The equity theory in the organization has been widely applied in practice and research, especially in the field of human resource management. In Vietnam, Nguyen (2010) tested a sample of 528 marketing employees in businesses in Ho Chi Minh City, applying the equity theory of Adams (1965) to identify the attributes (indicators) of factor "equity in firms". The finding is that "equity in a firm" includes three attributes: (i) I never feel that I am being used in the company, (ii) I have been adequately compensated when working overtime; (iii) In general, I am treated fairly within the company. Nguyen (2015) asserted that the decisions of managers always have two factors: technical factors (technical and financial calculations, etc.) and human factors. Both of these factors need to be addressed well. If managers only consider technical factors and disregard or ignore human factors, there will be no room for success in management because the human factor is the main issue bringing about consensus and support, which is a sufficient condition for the success of the organization.

\section{Research Methodology}

Inheriting the results of previous studies by Adams (1963, 1965); Greenberg (1990); Alexander \& Ruderman (1987), Moorman (1991), Lind \& Tyler (1988); Colquitt (2001). Coetzee (2004), Lee (2007), Nguyen (2010), Nguyen (2015) and by using a qualitative research approach namely interviews with selected experts to perform a quantitative research, we have identified equity in FDI firms (E) to determine the loyalty of accountants in Thanglong industrial park (LA). Then, we made a questionnaire consisting of 5 observation variables in a 5-point Likert scale. Independent variables are measured from 1 "without effect" to 5 "strongly" (see Table 1). The collection of data was accomplished through a survey of 150 accountants in Thanglong industrial park, for the period 2018-2019, close to this study period. Therefore, their feedback on the loyalty of accountants is considered very appropriate. Out of 150 questionnaires we sent, we received the feedback of 130 respondents. After checking the information on the returned questionnaires, we had only 105 questionnaires with full information for data entry and analysis, the size of this sample was consistent with study of Hair et al. (1998), namely $n=5 \times \mathrm{m}=5 \times 5=25$. Therefore, the rest of observations for model 1 are 105 surveys $(70.0 \%)$. Most respondents have bachelor degree or higher $(91.7 \%)$. As can be seen, all participants are at high quality knowledge, and this makes the survey reliable. We then used the EFA analysis and correlation analysis to determine the influence of equity in FDI firms determinant on the loyalty of accountants in Thanglong industrial park.

Dependent variable: The loyalty of accountants.

Independent variable: The independent variables are described in Table 1.

Table 1

Determinants and Its Coding

\begin{tabular}{|c|c|c|}
\hline Code & Scale & Source \\
\hline \multicolumn{3}{|c|}{ Equity in FDI firms (E) } \\
\hline E1 & Managers respect and treat me fairly. & Coetzee (2004), Nguyen (2010) \\
\hline E2 & $\begin{array}{l}\text { The management decisions of businesses are felt by accountants as reasonable, equal, clear and } \\
\text { unbiased. }\end{array}$ & Greenberg (2005); Lee (2007) \\
\hline E3 & Accountants have commitment, satisfaction with the job and put their trust in the management levels. & Alexander \& Ruderman (1987) \\
\hline E4 & Managers have appropriate working methods and assessments. & Colquitt (2001) \\
\hline E5 & I will be paid overtime bonuses when it is necessary to work overtime. & Nguyen (2010) \\
\hline
\end{tabular}




\subsection{Research Model}

From the above analysis, we have designed a research model as shown in Fig. 1.

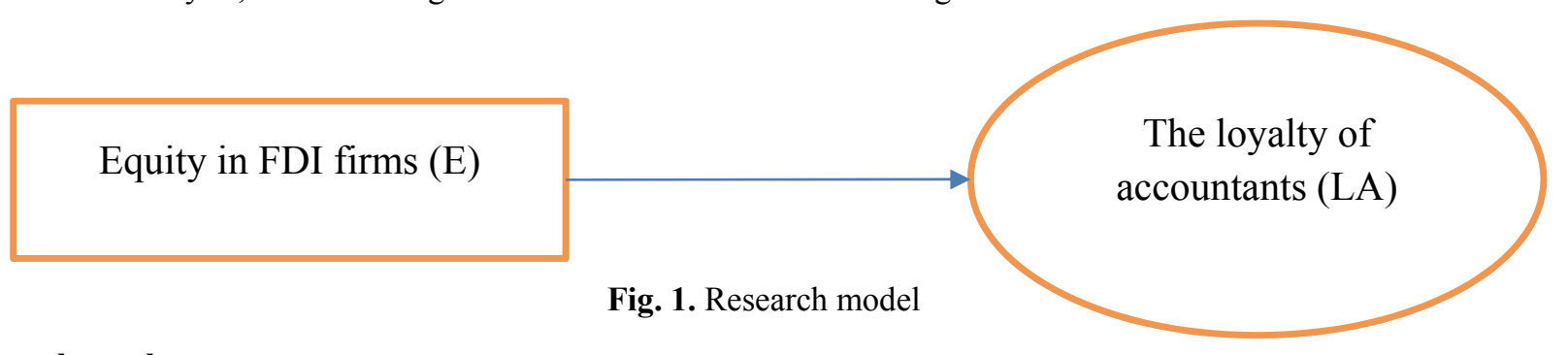

\section{Research results}

\subsection{Descriptive Statistics}

Fig. 2 presents details of the personal characteristics of the participants in this survey.

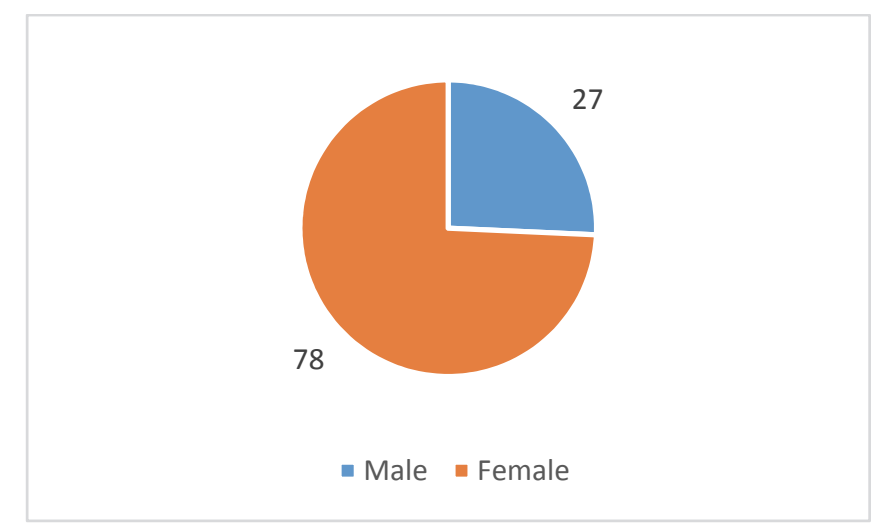

Gender

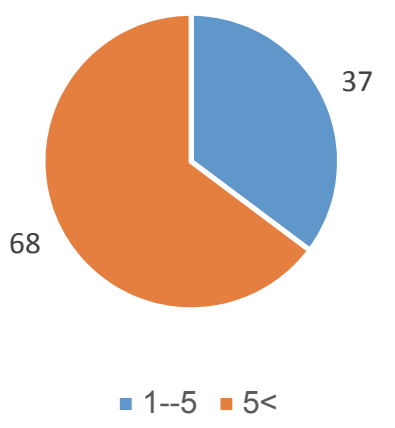

Seniority work

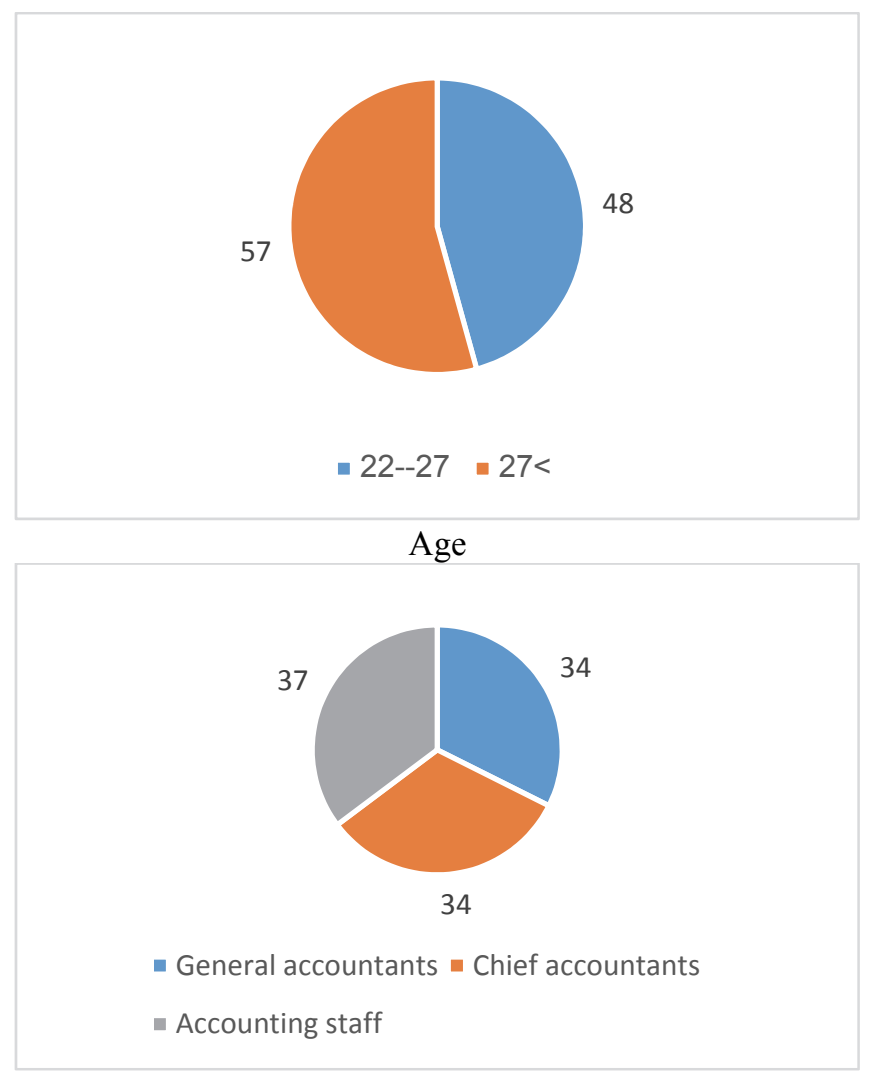

Job description

Fig. 2. Respondents by gender, age, job description, seniority work

Data in Fig. 2 show that among the 105 respondents, $25.7 \%$ of the participants were male while the remaining 78 were female, representing for $74.3 \%$. Of these, 48 of them aged 22 to 27 , accounting for $45.7 \%$; and $54.3 \%$ of the participants were over 27 years old. Among the 105 respondents, accounting staff, general accounting were represented for $35.2 \%$ and $32.4 \%$, respectively while the remaining $34(32.4 \%)$ were chief accountant. Of these, $35.2 \%$ of the participants have had from 1 to 5 years and the remining $64.8 \%$ had more than 5 years of job experience. 


\section{Table 2}

Descriptive Analysis of Attributes of Equity in FDI firms

\begin{tabular}{cccccc}
\hline & $\mathrm{N}$ & Minimum & Maximum & Mean & Std. Deviation \\
\hline E1 & 105 & 2.0 & 5.0 & 4.24 & .658 \\
E2 & 105 & 2.0 & 5.0 & 4.01 & .803 \\
E3 & 105 & 2.0 & 5.0 & 4.03 & .657 \\
E4 & 105 & 1.0 & 5.0 & 3.90 & 1.028 \\
E5 & 105 & 2.0 & 5.0 & 3.57 & .949 \\
\hline Valid N (listwise) & $\mathbf{1 0 5}$ & & & $\mathbf{3 . 9 5}$ & \\
\hline
\end{tabular}

Data in Table 2 illustrate that the respondents agree with the dependent variable of "Equity in FDI firms" where five attributes were quite high with an average of 3.95 compared with the highest of the Likert 5-point scale. All 5 attributes were rated at an average of 3.57 or higher.

\subsection{Cronbach's Alpha}

Equity in FDI firms has been measured by the Cronbach's Alpha with coefficient of 0.736. Results of testing Cronbach's alpha of attributes are presented in Table 3 as follows,

\section{Table 3}

Results of Cronbach's Alpha Testing of Attributes

\begin{tabular}{ccccc}
\hline & $\begin{array}{c}\text { Scale Mean if } \\
\text { Item Deleted }\end{array}$ & $\begin{array}{c}\text { Scale Variance if } \\
\text { Item Deleted }\end{array}$ & $\begin{array}{c}\text { Corrected Item- } \\
\text { Total Correlation }\end{array}$ & $\begin{array}{c}\text { Cronbach's Alpha if } \\
\text { Item Deleted }\end{array}$ \\
\hline E1 & 15.50 & 6.349 & .495 & .696 \\
E2 & 15.73 & 6.178 & .401 & .724 \\
E3 & 15.71 & 6.110 & .579 & .671 \\
E4 & 15.85 & 5.130 & .480 & .707 \\
E5 & 16.17 & 4.970 & .603 & .645 \\
\hline
\end{tabular}

The results also show that attributes of the independent variable had a Cronbach's Alpha coefficient greater than 0.6; the correlation coefficient of all attributes was greater than 0.3 , so all the attributes of the independent variable were statistically significant (Hoang \& Chu, 2008).

\subsection{Exploratory Factor Analysis (EFA)}

We then conducted Exploratory Factor Analysis (EFA) where the method of extracting coefficients were component and Varimax analyses of the 5 observed independent variables. As can be seen in Table 4 , the results of the EFA show that $0.5<\mathrm{KMO}$ $=0.648<1$. Bartlett's testimony shows sig. $=0.000<0.05$, which means that all variables are interrelated.

\section{Table 4}

KMO and Bartlett's Test

\begin{tabular}{lll}
\hline Kaiser-Meyer-Olkin Measure of Sampling Adequacy. & .648 \\
\hline Bartlett's Test of Sphericity & Approx. Chi-Square & 194.898 \\
& Df & 10 \\
& Sig. & 0.000 \\
\hline
\end{tabular}

After implementing the rotation matrix, we got the followings: one determinant with factor load $>0.5$, Eigenvalues $>1$, and the variance explained $=50.465 \%$. It demonstrates that the factor analysis of the research data is appropriate. Through the quality assurance of the scale and the test of the EFA model, one factor that influence on the loyalty of accountants of, i.e. Equity in FDI firms (E) was identified.

\subsection{Correlation analysis}

Table 5 presents the results of the correlation matrix of the factors. The correlation coefficient of one factor with dependent variable is $0.380>0$, reflect a positive relationship, sig. $=0.026<0.05$. It means that all variables are interrelated (Hoang \& Chu, 2008). 
Table 5

Correlations

\begin{tabular}{llcc}
\hline & & The loyalty of accountants & Equity in FDI firms \\
\hline \multirow{2}{*}{ The loyalty of accountants } & Pearson Correlation & 1 & .380 \\
& Sig. (2-tailed) & & .026 \\
& $\mathrm{~N}$ & 105 & 105 \\
\hline Equity in FDI firms & Pearson Correlation & .380 & 1 \\
& Sig. (2-tailed) & .026 & 105 \\
& $\mathrm{~N}$ & 105 & 105 \\
\hline
\end{tabular}

\section{Discussion and suggestions for governance implications}

The application of equity theory in management shows that the sense of fairness has a positive impact on the work efficiency, creates good relationships in the organization, builds trust and personal commitment to organizations. These are the main factors that affect organizational stability. Implementing equity also creates innovation for the organization (Kim \& Mauborgne, 1991). This is essential for human resource management, especially in the accounting sector, when there are many studies indicating that accounting personnel in Vietnam still have drawbacks, accountants do not meet practical requirements and the development of the integration economy in the future. Besides, Vietnam has not widely applied IFRS in the accounting system, in addition, there are few studies using equity theory to explain issues related to employees' loyalty, especially in the accounting sector when accounting and auditing is one of eight fields that have movability in the global integration era. Therefore, the application of this theory can shed light into in human resources management issues in general and accounting personnel management in particular. For the relationship between accountants and businesses, it is should be understood that once accountants feel the fairness in enterprises, they see what they receive is commensurate with what they contribute to businesses, their satisfaction level will improve, which creates favorable conditions for them to engage with their jobs and businesses. Therefore, FDI firms need to improve an equal environment in enterprises to stimulate employees' motivation in general and accountants, in particular, to engage with enterprises. Regular assessment in the perceptions of employees, including accountants about organizational equity should be taken into consideration. Moreover, FDI firms also need to compare fairness in their working environment with competitors, thereby making appropriate adjustments.

\section{References}

Adams, J. S. (1963). Towards an understanding of inequity. The Journal of Abnormal and Social Psychology, 67(5), 422.

Adams, J. S. (1965). Inequity in social exchange. In Advances in experimental social psychology (Vol. 2, pp. 267-299). Academic Press.

Alexander, S., \& Ruderman, M. (1987). The role of procedural and distributive justice in organizational behavior. Social Justice Research, 1(2), 177-198.

Coetzee, M. (2004). The fairness of affirmative action: An organizational perspective. Unpublished Doctorial Thesis, University of Pretoria, Pretoria.

Colquitt, J. A. (2001). On the dimensionality of organizational justice: A construct validation of a measure. Journal of applied psychology, 86(3), 386.

Colquitt, J. A., Greenberg, J., \& Zapata-Phelan, C. P. (2005). What is organizational justice? A historical overview. Handbook of organizational justice, 1, 3-58.

Greenberg, J. (1990). Organizational justice: Yesterday, today, and tomorrow. Journal of management, 16(2), 399-432.

Greenberg, J. (2005). Handbook of organizational justice. Mahwah, Erlbaum, New York.

Hair, J. F., Anderson, R. E., Tatham, R. L., \& Black, W. C. (1998). Multivariate data analysis. Englewood Cliff. New Jersey, USA, 5(3), 207-2019.

Hoang, T., \& Nguyen, M. N. C. (2008). Analysis of research data with SPSS. Vietnam: Hong Duc Publishing House.

Judge, T. A., \& Colquitt, J. A. (2004). Organizational justice and stress: the mediating role of work-family conflict. Journal of applied psychology, 89(3), 395.

Kim, W. C., \& Mauborgne, R. A. (1991). Implementing global strategies: The role of procedural justice. Strategic Management Journal, 12(S1), 125-143.

Lee, A. J. (2007). Organizational justice: A mediated model from individual well-being and social exchange theory perspectives (Doctoral dissertation, Touro University International).

Lind, E. A., \& Tyler, T. R. (1988). The social psychology of procedural justice. Springer Science \& Business Media.

Moorman, R. H. (1991). Relationship between organizational justice and organizational citizenship behaviors: Do fairness perceptions influence employee citizenship?. Journal of applied psychology, 76(6), 845.

Ngo, C.H.L., Nguyen, D.L., \& Nguyen, T.T.P. (2017). Determinants influencing the loyalty of employees in Exim bank Vietnam, Hochiminh branch. Asia Pacific economy journal, 4, 38-40. 
Nguyen, T.M.T. (2010). Determinants influencing the loyalty of marketing staff. Journal of Development Economic, 237, 2630.

Nguyen, V.T. (2015), Some contemporary theories about business management: application in research. National Economics University Publishing House, Hanoi.

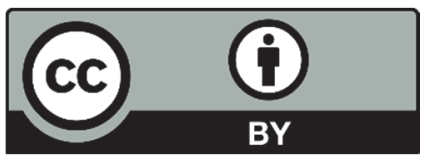

(C) 2019 by the authors; licensee Growing Science, Canada. This is an open access article distributed under the terms and conditions of the Creative Commons Attribution (CC-BY) license (http://creativecommons.org/licenses/by/4.0/). 